This is the version of the article accepted for publication in Settler Colonial Studies published by Taylor and Francis: https://www.tandfonline.com/loi/rset20

Accepted version downloaded from SOAS Research Online: http://eprints.soas.ac.uk/25980

\title{
Seeing Israel through Palestine: Knowledge Production as Anti-Colonial Praxis
}

By (in alphabetical order):

Yara Hawari (University of Exeter)*, Sharri Plonski (SOAS/University of London)** and Elian Weizman (SOAS/University of London)***

Email: yara.c.hawari@gmail.com*; sp46@soas.ac.uk**; ew26@ soas.ac.uk***

\begin{abstract}
Knowledge production in, for and by a settler-colonial state hinges on both productive and repressive practices that work together to render its history and present, 'normal'. The settler state aims to maintain hegemony over its agents, subjects, supporters and challengers by controlling, how, where, to and through whom it tells its story. This makes the production and dissemination of knowledge production an important battleground for anti-colonial counter-hegemonic struggles.
\end{abstract}

The State of Israel, in its ongoing search for patrons and partners in its colonising project in the Middle East, is especially focused on how to produce and appropriate 'knowledge', and the arenas in which it is developed and shared, to this purpose. In so doing, it works to reshape critique of its political, social and economic relations - in which the dispossession of the native is a ceaseless feature - and redefine the moral parameters that inform its legitimacy and entrench its irrefutability. Inspired by existing literature on and examples of anti-colonial struggles and practices of decolonisation, this paper investigates and challenges the myriad modalities through which Israel produces and normalises the colonial narrative. By critiquing existing representations and framings of the Israeli state - and the spaces and structures in which these take hold - our article contributes to the range of scholarship and communities of scholars working to radically recalibrate knowledge of 'Israel' and 'Palestine'. As part of this work, the article deliberately and purposefully centres indigenous anti-colonial frameworks that reconnect intellectual analysis of settler colonial relations, with political engagements in the practice/praxis of liberation and decolonisation.

\section{Keywords}

Israel Studies; Indigenous and Settler Colonial Studies; hegemony and counter hegemony; critical pedagogy; anti-colonial/decolonising praxis

\section{Introduction}

Ladies and gentlemen, we live in a world steeped in tyranny and terror where gays are hanged from cranes in Tehran, political prisoners are executed in Gaza, young girls are abducted en masse in Nigeria, and hundreds of thousands are butchered in Syria, Libya and Iraq, yet nearly half -- nearly half of the UN Human Rights Council's resolutions focusing on a single country have been directed against Israel, the one true democracy in the Middle East; Israel, where issues are openly debated in a boisterous parliament, where human rights are protected -- by independent courts, and where women, gays and minorities live in a genuinely free society.

Benjamin Netanyahu Address to the UN, 29 September $2014^{1}$

The Younes \& Soraya Nazarian Center for Israel Studies promotes the study of the history, culture and society of Israel as a modern Jewish and democratic state...Israel is a tiny country that looms large in public and academic discourse. The 


\begin{abstract}
passions it evokes often present obstacles to balanced analysis and evenhanded discussion. In the six decades since its founding, the State of Israel has spawned a vibrant culture and a multiethnic democracy. It has also faced ongoing challenges and has had to grapple with complex geopolitical issues. An appreciation of the complexities that are Israel requires knowledge, probing analysis and dialogue across different disciplines and viewpoints. Through a commitment to academic rigor and interdisciplinary approaches, the Nazarian Center fosters a broad understanding of Israel and its place in the region and the world."
\end{abstract}

The Younes \& Soraya Nazarian Center for Israel Studies, UCLA 'About US'

The two quotes above expose the multiple terrains upon which Israel is currently battling for legitimacy. In the first of these, Benjamin Netanyahu, Israel's Prime Minister, stands on the UN stage, selling the image of Israel as the stable bastion of 'civilisation' in the Middle East to a global audience; a part of the world that Western/US audiences have positioned as the 'heart of darkness' in their global imaginary. In the second, UCLA's Israel Studies Programme describes the rigorous tools needed - and which it offers - to understand Israel's vibrant 'multiethnic democracy' and grapple with the complexities that constitute its social, political and geographic relationships. Together, they highlight key aspects of Israel's struggle for saliency: first, that the sites of engagement are situated well beyond its own geography or populations. As Shihade also notes, this audience is primarily 'Western', with Israel's spokespeople speaking directly to the West's racial and geo-economic anxieties about a part of the world it sees as unfamiliar, unstable and thus threatening. ${ }^{3}$ Accordingly, the approach is sophisticated, steeped in seemingly universalist and liberal values. ${ }^{4}$ Second, that all stages are deemed potential frontiers, where Israel's control of the political discourse - and the right to determine its moral parametres - is insecure. The UN and university campuses are not the only sites; international media, diplomatic exchanges, economic and security fairs, even tourist information and googlemaps are potential opportunities for articulating Israel's legitimacy, with recent 'battles' taking place at INTERPOL, the International Criminal Court and UNESCO, among others, with mixed results for Israel. Third, the discussion of those with whom Israel 'battles' - the Palestinians - is contained and restrained, so that when they are discussed, it becomes one of many 'issues' that constitute Israel's story.

The practices of presenting and marketing Israel to an international audience, whether in the academy or to the wider public, launder Israel's past and present; hiding the violence of colonial disruptions and expulsions beneath articulations of moral legitimacy, national longing and belonging, and the right to claim sovereignty over territory, law and life in Palestine. These are then further buried beneath Israel's global 'brand' of high tech and entrepreneurial prowess, of gay-friendly street parties in Tel Aviv, of a 'diverse', 'complex', 'multicultural', 'democracy' (but, 'not without its problems'); a 'station' (as we read in Joseph Conrad's work) capable of pacifying and connecting - or containing and securing - an unstable, undemocratic and deeply insecure Middle East, to the rest of the world. ${ }^{5}$ This image has been contrived through multiple levels of campaigning, including by stakeholders involved in the now-infamous 'Brand Israel Group', a collective of media moguls (mostly US-based), working alongside Israel's Ministry of Foreign Affairs, committed to reinventing Israel as a relevant and modern state (as opposed to a place of conflict and religious affiliation). ${ }^{6}$ Netanyahu's bluster on the world stage, depicted in his UN speech, quoted above, has been essential to producing and selling the brand - and it is one that a plethora of governments and multinational companies have clearly bought into, bolstering the idea that Israel is a necessary partner in global trade and security, while building the material infrastructure that entrenches the settler state and makes it permanent. ${ }^{7}$

Our paper, while steeped in discussion of the settler colonial character of the Israeli state, is less interested in the violence it produces, than in the myriad modalities through which these are normalised and thus hidden from plain sight. As is clear from the above, Israel is constantly seeking new ways to make itself abstract and unknowable, and at the same time fixed, solid and irrefutable. This is an unending and unfinished project, indelibly tied to the unending and unfinished territorial project, with its incompleteness anchored in the fact that the Indigenous Palestinians continue to resist its structures ${ }^{8}$. Our focus is on how to unravel and re-articulate how the 'story' of Israel is told, to 
itself and others; seeing this as key to the assemblage of material and discursive practices operating to erase and replace Palestine, on multiple front lines, in multiple places.

In what follows, we are working, on the one hand, to highlight the expanding effects of 'the Israel Studies paradigm': on the way Israel is treated in academic programmes as a 'normal state', yet exceptional and thus carved out of regional and global politics; and, given its growing absorption of critical interrogations into Israeli state and society, on the shift in Palestine Studies against explicit investigations into the logistics of settler spaces and social relations (as part of and relevant to studies of Palestine). On the other, we seek to contribute to the community of scholars developing a variety of radical frameworks for recalibrating knowledge of Israel and Palestine. These are working to centre indigenous anti-colonial approaches to settler colonial relations and reconnect intellectual practices that engage an understanding of the settler colonial framework, with political ones, engaged in the practice/praxis of liberation and decolonisation.

As shall become clearer in the discussion below, this involves de-mystifying the settler project in Palestine, understanding why and how Israel hides its colonial character and modes of violence in liberal matrixes, and emphasising the importance of educational technologies to both bolstering and unsettling how Israel cultivates hegemony over how we know and see Palestine. It also requires thinking about what is or should be the centre of this analytical project, who or what is often left out (and why), and what spaces, frameworks and discourses are conducive to disrupting or divesting from, as opposed to condoning, the kinds of power relations that maintain settler colonial relations. By looking through the lens of Israel Studies, as part of the institutionalisation of settler knowledge production in academic, political and economic arenas, we are able to map this process, find its holes and contradictions and look for new ways of re-articulating how Israel is discussed and challenged. In so doing, we work to shift our empirical and theoretical encounters with Palestine, engaging with fields of study that radically challenge mainstream and critical ways of knowing, writing and historicising settler colonial relations.

This investigation is inspired and influenced by existing literature on anticolonial struggles and practices of decolonisation, deriving from historical and contemporary experiences of resistance to settler colonialism around the world. In the following sections, we develop a way of thinking through this literature and practice, based on our collective and individual research into the ontologies of resistance to the settler colonial condition in Palestine. We also build on multiple conversations that have evolved over several workshops and conference roundtables we have organised or participated in over the past year, in Jerusalem, London, Edinburgh and Barcelona. These have involved scholars at different stages of their career, discussing these issues from a variety of personal and professional lenses, and to whom we are indebted. Drawing inspiration from Corey Snelgrove, Rita Dhamoon and Jeff Corntassel's collaborative work on the topic, we also acknowledge that our individual structured positions guide our analysis and writing. ${ }^{9}$ Yet, even as our identities clearly inform our analytical engagements with Palestine, we would like to use them as points of strength; entry points from which to critically reflect on the nature of settler colonial relations, of which we are each a part, albeit in starkly distinct ways. ${ }^{10}$ With this piece of writing, we attempt to re-calibrate the analytical and political tools with which we engage and understand Palestine and the Zionist project, with a view to resisting these realities on the ground and the way knowledge is produced about them.

\section{Institutionalising knowledge about the Israeli State: the case of Israel Studies}

The production of knowledge in, for, and by a settler-colonial state hinges on both productive and repressive practices that work together to render its history and present as 'normal'. It reshapes critiques of capitalist and colonial social relations - in which the dispossession of the native is an ongoing and ceaseless feature - to give it moral parameters, through which to assert and entrench its legitimacy. ${ }^{11}$ Understanding this has crucial bearing on how we shape our analysis of the proliferation of Israel Studies programmes across university campuses, as well as our contention that anticolonial praxis, grounded in indigenous epistemologies and movements, is key to challenging settler colonial knowledge production. 
In this regard, Glen Coulthard's approach to the hegemonic nature of settler colonial relations is insightful. In his work on the politics of recognition among Canadian first nation communities, he echoes and expands on Antonio Gramsci's formulations, in which the strength and stability of the system of power is derived from the production of consent, underwritten by modes of force and coercion. ${ }^{12}$ In Coulthard's depiction, power in the liberal settler colonial state is garnered from 'its ability to produce forms of life that make settler-colonialism's constitutive hierarchies seem natural'. ${ }^{13}$ Expanding on these themes, Coulthard further explains that the settler colonial relationship is 'one characterised by a particular form of domination, where power [...] has been structured into a relatively secure or sedimented set of hierarchical social relations that continue to facilitate the dispossession of indigenous peoples of their lands and self-determining authority'. ${ }^{14}$ In navigating the delicate balance between coercion and consent, the settler state provides resilience to its moral claims, its structures and its logics of operation, which in turn cultivates the internal and international legitimacy and support it requires to make its claims to indigenous territories.

The logic of 'liberal' settler states, such as Canada, the US, Australia, New Zealand, and Israel, relies on the production of subjects and supporters in its control and surveillance of indigenous populations, in addition to structural and more direct acts of violence. Members of the colonising society, the international community, and even colonised communities are weaved into the overall project, through the ordering of space, movement and the circuits and engagements of everyday life. The sites, methods and technologies of 'knowledge production' in the settler state are key anchors in sustaining, maintaining and challenging hegemony. As ways of knowing the world elide with the hegemonic system, it becomes difficult to think outside its existing frames and limits. Even more problematic, in addition to silencing dissent or actively repressing indigenous knowledge (which holds within it contentious claims to who and what is privileged and produced in the colonial state), the system operates to incorporate and hence neutralise or flatten the politics of these different and challenging voices. ${ }^{15}$ Even though it is also rife with contradictions and inconsistencies, knowledge produced in support of a settler colonial common sense, is also flexible and constantly evolving; a structure that is contingent and elastic, making it difficult to unpack and challenge. As we contemplate the field of Israel Studies as a site and practice of settler-colonial knowledge production, it is with this complexity in mind.

While the study (and normalisation) of Israel has a long history in academia, over the last decade, Israel Studies' chairs and programmes have mushroomed across university campuses. ${ }^{16}$ More than 40 have found homes throughout UK and North American universities - a number that excludes centres in the Middle East, including Israel, as well as the plethora of visiting established researchers, postdoctoral students and doctoral candidates that also make up these programmes. These positions represent millions of pounds of institutional funding, from both private individuals and philanthropic organisations. ${ }^{17}$ They have been carved out of regional studies of the Middle East in academia - some with their own centres, others as part of revamped 'Jewish Studies' programmes - ostensibly in response to the increasing relevance of Israel to scholarly understanding of modern politics. ${ }^{18}$ On the surface, it is a complex field of study. Conceived as 'borderless', allegedly formed in conversation with so much more than 'the Middle East', Israel Studies grapples with the Jewish Diaspora and Jewish identity, the history and impact of the translation of European-Zionist ideology into a statebuilding project in Palestine, and the ongoing geo-politics of the region that include volatile internal and external social-spatial relationships. ${ }^{19}$ Yet, its invention as an integral arena of study cannot be divested from the political sphere in which it is situated - as an outpost of Israel (or rather, the 'Israeli perspective' on the 'conflict' with Palestine/the Middle East), fighting for space in 'enemy territory'. ${ }^{20}$ Nor can Israel Studies be divested from the politics that underwrite endowments by philanthropic associations intimately tied to the Israeli state's 'hasbara' (propaganda) efforts, ${ }^{21}$ even as critical scholars take up these posts and articulate diligent and even radical scholarship in their treatment of Israeli social and political space.

As a site for the (re)production and normalisation of settler colonial knowledge, Israel Studies should be considered on its own terms, as well as a signifier for how Israel as a state functions and represents 
itself. It becomes a mirror for Israel's own dislocation and isolation from the region - a gated colony of Europe in the Middle East - and its modes for obfuscating the violence of this project. In rooting and institutionalising Israel Studies in the academy (through international conferences, academic journals and multiple associations and institutions), ${ }^{22}$ it makes Israel (as well as the study of Israel), appear familiar and complex. That said, it is important to understand the academic space itself, as Magid Shihade, Walter Mignolo and Achille Mbembe argue, as essential to the production of 'Western' hegemony and colonial privilege, ${ }^{23}$ and thus Israel Studies as part of (rather than exceptional to) how academia articulates, veils and promulgates colonial and capitalist relations, historically and in the present. Thus, when the study of Israel is folded into Israel Studies, its particular frame, narrative and agenda inform and are informed by an existing and evolving set of interests, in which indigenous claims, approaches and knowledge are already effaced. In the context of Israel/Palestine, this has meant a series of key excisions, many of which have already been alluded to above: Palestine is seen as an exceptional case, distinct from other sites of colonial conquest, along with Zionism/Israel, which is seen as distinct from other national and settler colonial projects. When discussion is situated on Palestine or Palestinians, history often begins in 1967, 'Occupation' is (at best) the ontological category for thinking through Palestinian relations with Israel, ${ }^{24}$ and geography begins and ends with the 'Green Line'. Devoid of historical and geographic connections to the process of making and unmaking the Zionist state in Palestine, scholars tend to focus on fractured categories of violations that ultimately flatten analyses of power, technologies of violence, and the social productions of race generated as part of settler colonial relations. ${ }^{25}$ This also tends towards either leaving out or misrepresenting anti-colonial acts of resistance by indigenous groups, which constitutes a spectrum of individual and collective actions that intervene in the flows of power. And of course, Israel is always the centre and starting point.

This is not to say that these programmes do not offer rigorous explorations of the internal inconsistencies and inequalities that constitute Israeli society and politics; or the inherent violence of its project in Palestine. However, as the quote from the UCLA programme illustrates, they often do so along a continuum of alleged objectivity and plurality; obfuscating a bias for the status quo of power relations by developing a platform from which all discourses, whether coming from the 'right' or 'left', share legitimacy. By comparison, as exemplified in the 2016 case of UC Berkeley repealing (and later reinstating) a student-initiated course on settler colonial relations in Palestine, the politicisation of Israel is deemed unruly, unscholarly and ideologically-led. ${ }^{26}$ From here, Israel Studies programmes' almost ubiquitous calls for 'engagement and dialogue' garner legitimacy and moral supremacy. This is especially the case when comparisons are made with centres and associations that critically engage in the study of Palestine, calling for boycott or sanctions of the Israeli state or its institutional arms; in their work towards aligning the intellectual project with the needs of the political one, they are made to seem beyond the pale of academic rigour. ${ }^{27}$ Interestingly, this echoes (and reinforces) the 'pluralist', allegedly 'modern and democratic' tropes that the Israeli state prides itself on, as expressed in the quote above taken from Netanyahu's UN speech; which, as Himmat Zu'bi points out, is a key facet of the state's modalities for negating Palestinian knowledge, actions and articulations of Israel, and consequently, their physical presence in the territory it controls. ${ }^{28}$ Thus, we should not consider what is happening in academic spheres as taking place in a vacuum, but rather as part of these processes which feed into and from one another.

The approach turns indigenous experiences of settler colonial relations into something that can be debated, with the effect of containing and reframing the fault lines and limits to critical engagement on Palestine. In the academic arena, this has produced an intellectual culture that demands that all public platforms dealing with Palestine incorporate both 'sides', lest they be labelled 'political' and 'biased' (and thus illegitimate). To reiterate, this tends to truncate radical, anti-colonial analyses, and in particular silences Palestinian researchers and activists who do not want to be drawn into this legitimising exercise. This is clear in Yara Hawari and Hana Sleiman's descriptions of a conference they attended at Sussex University in May 2017 on '50 Years of the Occupation'. With few Palestinian researchers present (many withdrawing upon seeing the final programme), and with the organisers' attempt to offer a 'balanced viewpoint' of 'the conflict' by inviting non-critical scholars to speak alongside more critical ones, the performative polemics of 'debate' replaced creative or 
productive engagements with the history, present or future of settler colonialism in Palestine. The conference ended with one of the organisers aggressively berating Hawari and Sleiman, both Palestinian UK-based doctoral researchers, for pointing out the inherent problem in framing the conference in this way. ${ }^{29}$

Hilary Aked's work, which documents the politics that underwrite the carving out of Israel Studies as an academic field in UK institutions, confirms the importance placed on maintaining this tension in academic spaces; keeping the debate alive and unfinished, and thus strangling and stagnating the discourse. As several interlocutors of the philanthropic organisations that fund these programmes admit, Israel Studies offers a space to push back against de-legitimisation discourses, to re-centre Israel (and thus de-centre Palestine), to close down as well as re-orient the lenses through which Israeli state and society are examined. ${ }^{30}$ This has led to one of the most problematic effects of the promulgation of these programmes - as well as one of its greatest successes: Israel Studies has become the home for critical discussions of Israel, carved out and separated from critical studies of the Middle East or Palestine. Within this epistemic space, the terms by which radical analysis of Israel can (or cannot) take place, are easily re-defined. The result is not only the de-politicisation of the study of Israel, but, given that it coincides with a gradual trend among radical fields of indigenous and (post)colonial studies (including Palestine Studies), Israel is increasingly dismissed as an irrelevant sphere of analysis to the study of Palestine, and the study of the Middle East.

This has left a vacuum in the field, wherein the particular logistics through which Israel territorialises and disciplines social-spatial relations in Palestine are left un-interrogated and much less understood. Without this understanding, Israel as a colonial state becomes pervasive, tautological, unending and thus unchallengeable; which we would argue, more than simply silencing the other, has been the point all along. Yet, in rooting this discussion in the hegemonic nature of the liberal settler state, we should remember that hegemony is a process, an open-ended construction, and its forms can be partial, strong or weak, and include concealed contradictions and fractures, as well as meanings and resources that are not fully controllable. As Gramsci argues, hegemony constitutes an ongoing struggle, pulling in (at least) two directions simultaneously - maintaining the status quo and turning it on its head, with the potential for the construction of counter-hegemony. Counter-hegemonic practices work to undermine the existing hegemonic system, by pressuring it out of balance; forcing it to reveal the oppressive and violent apparatus with which order and control are in fact maintained. In his discussion of (counter)hegemony, Gramsci puts emphasis on the creation of a new 'collective will', a new understanding of reality that can unite society around a political struggle. ${ }^{31}$ To achieve this, it is imperative to disintegrate the bases upon which the existing hegemony rests: this process is first and foremost an educational one, grounded in and intrinsically linked to struggle.

\section{Education as anti-colonial praxis}

While education plays a prominent role in the sustainment of hegemony and its status quo, it plays an indispensable role in the counter-hegemonic revolutionary process. On the importance of education in the struggle for liberation from oppression, the writing of the Brazilian educator Paulo Freire is instructive. What Freire terms critical pedagogy constitutes a revolutionary strategy that centres upon the transformative power of ideas, education and intellectuals. For Freire, pedagogy 'makes oppression and its causes, objects of reflection [...], and from that reflection will come the[ir] necessary engagement in the struggle for their liberation'. ${ }^{32}$ Accordingly, a counter-hegemonic project is grounded in the politics of knowledge as the facilitator of social change: knowledge that creates new sensibilities, a new language and with it a new type of political subject.

Since the settler colonial drive is anchored in the complete takeover of territory and erasure of the native's presence - an evolving process of normalising and affixing the settler's presence on the land and with it, the hierarchies, structures and constructions of the colonial relationship ${ }^{33}$ - the struggle to decolonise is bound up with negating this very process. It is about de-normalising and rejecting the production of settler knowledge; and at the same time constructing alternative knowledge that can 
support and sustain a decolonised future. Accordingly, the work to decolonise knowledge should be understood as part of the larger counter-hegemonic project, one that rejects existing representations and denies the normalisation of existing power relations. Yet, it is, as Gramsci argues, something that happens gradually, evolving through the production of subjects and supporters, and incorporated into the institutions and ideologies that constitute state and society. Thus, we would argue that the struggle for liberation from oppression, for the decolonisation of life and land in settler states, calls for a 'war of position', fought in the trenches of civil society, of state institutions, in daily life. ${ }^{34}$

In Rita Dhamoon's work on the expansive nature of settler colonial hegemony, she explains that while settler colonialism is a 'structure', at the same time, it is not a 'meta structure'. On the contrary, 'It is composed of a series of structures and processes, and also part of a series of structures of domination or a matrix of domination. In other words, settler colonialism is both generative of and generated by intersecting and interactive forces of power' ${ }^{35}$ The implication of this is significant for a praxis of decolonisation, as it opens up the space for resistance and for change. It foments the possibility of creating alliances and collective action, in order to disrupt and expose as well as confront multiple dimensions of the matrix of domination, simultaneously, and develop new frames, new ways of knowing, and new ways of thinking.

Anticolonial theory 'cogently speaks to the imperial present from, with, through and against the colonial past', and forms an alternative body of knowledge that is instilled through local knowledge. ${ }^{36}$ Drawing inspiration from anticolonial thinkers, the praxis of anti-colonial/decolonial knowledge production must therefore include several facets. First and foremost, it must be part of a liberatory movement, committed to challenging and dismantling colonial imposition, and all relations of domination. In parallel, it must engage in the empirical and theoretical study of the nature and extent of particular and general relations of domination and the multiple sites of power. This work should be grounded in the understanding that decolonial knowledge is 'an epistemology of the colonized, anchored in the Indigenous sense of collective and common colonial consciousness'. ${ }^{37}$ This does not simply demand a reoriented lens, but a practice that shifts how we think and do research, with the potential towards transformation.

Thinking through the role and function of contemporary Israel Studies in this light, reveals the need to confront and unravel its premises and its modes of operation; to contest it by advancing, rather than dismissing, understanding of Israeli state and society. It is our contention that redrawing the parameters around which Israel is studied, and thus encountering Israel in its raw and problematic form as part of how Palestine is studied and engaged with, is key to challenging and dismantling the new hegemony of Israel Studies; and to reconnecting the intellectual examination of Israel with the movement to liberate Palestine. We argue that what is needed is precise analyses of the material history of Israel's settler-colonial project, as well as the assemblage of educational practices used to bolster it, in order to carve out a vision for how to challenge and transform it, and ultimately decolonise it. To do so, it will be necessary to shift the voices and lenses through which this develops: to begin by emphasising, as Zu'bi, Mbembe and Linda Tuhiwai Smith do, the colonising effects of settler knowledge production, which sees indigenous peoples as objects of research as opposed to subjects; and thus to work, as Timothy Mitchell argues regarding the colonisation of Egypt, through the lens of colonised peoples to analyse the coloniser, and thus the indigenous experience of colonisation. And then, with this knowledge as a guide, we need to develop an educational practice in which the agents and subjects of knowledge and research are turned on their head. ${ }^{38}$

However, we argue that in order to recalibrate how we approach the study of Israel we must first take into account the shifting terrain within Palestine Studies, particularly in its engagements with critical paradigms. In particular, we must consider the call by Shihade and others for the decolonisation of Palestine Studies through the framework of Indigenous (and anti-colonial) knowledge; a demand that is more than a call to look at Israel through a settler colonial lens, but to understand how studies of and in the Middle East have been shaped by settler colonial and neoliberal hegemony, and thus must be challenged and transformed. ${ }^{39}$ 


\section{Finding New Terrain in Critical Studies of Palestine and Israel}

In 2013, the guest editors of the special issue of the Journal of Settler Colonial Studies, titled 'Past is Present: Settler Colonialism in Palestine' called for a new praxis for the study of Palestine, in which decolonisation and liberation are reclaimed as part of our analytical reading of the case..$^{40}$ The essence of their argument focused on the severed link between liberation methodologies and analytical rigour in the study of Palestine and the resulting lost engagement/relationship between 'movement' and 'scholarship' that once shaped the core of the field. ${ }^{41}$ They argued that the shift was informed by new politics and priorities since the inauguration of 'the Oslo Process' that concentrated Palestine into a confined territorial space whilst at the same time failing to address its past and present. The effect of this has been to erase the ongoing colonial legacy of Zionism (inside and outside academia) and to normalise settler colonial relations in Palestine. The call was an attempt to realign the fractured and flattened analysis of racialised violence, dispossession and elimination in Palestine, with both old and new frameworks for conceptualising these as part of the global project of settler colonial and capitalist relations. The practicalities of this requires engagement in comparative, intersectional analysis that situates Zionist settler colonialism as part of, as Lorenzo Veracini labels it, the 'settler colonial present', ${ }^{42}$ and treats the anticolonial struggle in Palestine as 'embedded within, and empowered by, broader struggles - all anti-imperial, all anti-racist, and all struggling to make another world possible' ${ }^{43}$ Moreover, crucially, the new trajectory of scholarship, they argued, must reiterate the fact that 'Palestinians are an indigenous people, and (there must be) an alignment of Palestine scholarship with indigenous and native studies' ${ }^{44}$

One should see the 2012 special issue as part (rather than the initiator) of this shift in both the field of critical Palestine Studies and the disciplinary conversation around settler colonialism; a zeitgeist once again mirroring politics on the ground. In parallel with the failings of Oslo, ${ }^{45}$ a floodgate of new research had been opened that has re-rendered Palestine through the lens of 'settler colonialism'; at the same time, Settler Colonial Studies increasingly became centred on Palestine, re-writing its structural features through analyses of this case. ${ }^{46}$ This range of work has succeeded in revealing the violence of Israel as a settler state in high-profile journals, academic conferences, university classrooms and disciplinary associations, and thus in achieving its goals of re-configuring the conversation around Israel in critical academic circles. Yet, these successes, which are still partial and often marginalised within academic institutional spaces, emphasise both the ways in which critical research contributes to counter-hegemonic practices, and how hegemonic knowledge is reasserted and reproduced, as it contends with the new turn in Settler Colonial Studies.

This is evident if we consider that while the new research agenda in critical Palestine Studies is clearly anchored in the scholarly legacy of Palestine liberation research (initially outlined in 1965 by the PLO Research Centre), it also seems decidedly distant from it - to such a degree that, as Barakat has noted, it is barely ever referenced..$^{47}$ Researchers from this earlier period found their inspiration and comparative landscape from post-colonial African states that had fought and won their liberation struggles, with Fanon as their theoretical mouthpiece and Algeria as their signpost (and ultimately, renewing this connection was at the heart of the special issue's call for analytical resurgence) ${ }^{48}$ Conversely, current scholarship increasingly places Palestine alongside those states whose settler projects have remained resilient by embedding themselves in liberal and neoliberal state structures such as in the US, Canada, Australia and New Zealand. This has connected the trajectory of this research with the paradigm developed by Patrick Wolfe (and later Veracini), in which settler colonialism is a 'structure not an event', and elimination - which is both a 'logic' and a 'practice' operates at multiple levels and in multiple ways to efface indigenous systems of life and territoriality. As part of this process, settlers re-write the legal, geographic and social matrix of their new homes, enabling them to hide (and even forget) their character, becoming natives, through normalising their privileges and modes of violence. ${ }^{49}$

The issue highlighted here is not the shift in comparative case studies, nor the new depth with which Wolfe and Veracini understood the distinctiveness of settler colonialism vis-a-vis other colonial projects. Both the Algerian and the American context are relevant and enrich analyses of settler 
colonial relations in Palestine and vice versa. However, as Algeria and other post-colonial states have disappeared from the cutting edge of settler colonial analytics (in Palestine and elsewhere) ${ }^{50}$ research priorities have shifted from how settler colonialism ends, to how it continues. The subtlety of this change makes discussion of anti-colonial resistance, indigenous futurity, and decolonisation less concrete; and thus settler colonial relations has become an increasingly comfortable terrain for interrogation in spaces and among scholars that are disconnected from political movements on the ground. This is not to say that settler colonialism is not still a trigger to those seeking to control the discourse around Israel, given the problematic questions it poses around Israel's 'normal' status in the world (as the Berkeley example cited above clearly demonstrates). Yet, as it is increasingly folded into academic arenas, and given legitimacy within hegemonic institutions, settler colonialism becomes another debated, intellectual framework: a way of understanding a system of power, divorced from practices actually seeking to transform it. To the point, where such paradigms feel comfortable and ordinary in spaces and systems they are meant to disrupt. ${ }^{51}$

Thus, in navigating sites of hegemonic knowledge production, it will not be enough to simply study Israel (or any settler colonial state) through 'the Settler Colonial paradigm', as it is often labelled. It will require turning the framework on its head, to look at Israel through the lens of Palestine; to look at settler colonialism through the lens of those who want to end it and link it to the goal of decolonisation. ${ }^{52}$ Following the lead offered by many Indigenous scholars and scholars of Indigenous Studies, it is our contention that lessons for how and from where to start will come from working within the frame offered by 'Indigenous Studies' - a body of scholarship and community of scholars that link an analytical process to its material goals, and treat knowledge production as both a theory and a praxis, upon which collective organising is based. Yet, the large-scale embrace of settler colonial studies by Palestinian scholars and scholars of Palestine Studies has also been accompanied with some apprehension on locating scholarship on Palestine within Indigenous Studies. This has also been reflected in the Palestinian national political project, as perhaps best exemplified by the statement made by Yasser Arafat during the siege of his compound in 2004 by the Israeli army, in which he stated "We are not Red Indians". ${ }^{53}$ Although it is beyond the scope of this article to address Indigeneity as it is understood within the Palestinian national project, this statement by Arafat reveals an important and common assumption about Indigenous peoples that is also present amongst those scholars working in the field: that the settler colonial project has been successful in North America and that the 'Red Indians' have been wiped out. Indeed, Nadim Rouhana, drawing upon (albeit misrepresenting) Mahmoud Mamdani's explorations of settler colonial typologies, explains that unlike North America, where settler colonialism has triumphed, the Zionist settler colonial project is ongoing and "its outcome is still undetermined". ${ }^{54}$ Rouhana goes on to describe the exceptionality of the Israeli settler colonial case 'because its main goal is still actively challenged and resisted by a nation that Zionism has defeated but failed to reduce to the status of indigenous populations in 'triumphed' settler-colonial cases'. ${ }^{55}$ As exemplified in the work of Audra Simpson, Coulthard, Tuhiwai Smith and others - not to mention ongoing and powerful movements for Indigenous sovereignty throughout the continent - this dismissal of Indigenous peoples and Indigenous struggles in North America ultimately relegates the settler colonial structure (in Palestine, as much as anywhere else) to an event, fixed and limited to a particular space and time. ${ }^{56}$

These undertones of defeat, fragility and extinction that are evoked with discussion of indigeneity, are reflected among some of those working within the academic field of Palestine Studies, and have become a key facet of the hegemonic approaches we are seeking to disrupt. This notion of extinction has serious temporal implications as it relegates Indigenous peoples to history, with settler colonialism as something that happened to them rather than something that continues to happen to them. It moreover problematically situates Israel in ahistorical terms - an exception that leads to a lack of comparative analysis between Palestinians and other indigenous peoples, despite the paradoxical use of settler colonial analytics as a way of understanding the state's logics and actions. Brenna Bhandar and Rafeef Ziadah highlight this problem and make the case for a comparative approach within settler colonial scholarship and political organising circles that "must attend to the politicaleconomic and juridical formations that subtend colonization as a process" ${ }^{57}$ Steven Salaita similarly argues that Indigeneity must be conceptualised as a global political category and as such, 
decolonisation in Palestine must be part and parcel of a global process. ${ }^{58}$ The term Indigenous peoples is thus one that connotes and connects people's experiences and struggles in the face of ongoing colonisation; an idea we believe is central to the decolonising of knowledge of settler relations in Palestine ${ }^{59}$.

The growing discord between Settler Colonial and Indigenous Studies further highlights the tensions between separating the discipline from the movement, and the need to reconnect them in critical studies of Palestine. These tensions become clear in an emerging critique of the settler colonial paradigm, articulated by Alissa Macoun and Elizabeth Strakosch, as 'a largely White attempt to think through contemporary colonial relationships' ${ }^{60}$ Indeed whilst Indigenous Studies is largely a scholarly endeavour dominated by Indigenous scholars, Settler Colonial Studies is conversely dominated by non-Indigenous scholars. While this has not been the case for scholarship on Palestine, where many Palestinian academics have contributed to and advanced the framework (as discussed above), we note a new palatability to the paradigm within Israeli institutions and centres of knowledge. ${ }^{61}$

This seems to follow from the field's focus on, and centring of, the dominating power structure. As Jodi Byrd writes;

One of the challenges facing Indigenous Studies in conversation with Settler Colonial Studies and frontier histories is to resist the continual prioritizing of an effect for a cause, of requiring the settler and the frontier rather than the indigenous as the structuring analytic through which to assess the consequences of colonialism. ${ }^{62}$

Byrd highlights the possible epistemic trap of focusing the narrative on the settler structure and therefore replicating the silencing of Indigenous voices. The disruption of these colonising epistemologies in academia must thus be positioned as the driving impetus behind white scholars who consider themselves as allies to non-white and indigenous peoples. Recognising this dynamic, Wolfe had previously discussed the problematic position of white settlers dominating knowledge production within Indigenous studies:

I set up the teaching of Koori history - that's indigenous southeast Australian history - at the University of Melbourne...I gave it up after a few years because I am a Gubbah - a white guy - and it seemed wrong to me that a white guy should be teaching Aboriginal history when there weren't any Aboriginal people also teaching it. ${ }^{63}$

Wolfe crucially points out the troubling power structure involved when a white settler is the sole producer of knowledge on Indigenous peoples within an institution; one that is uncomfortably reiterated in the proliferation of Israel Studies' programmes (as opposed to 'Palestine Studies' programmes) and their narrations of Palestinian history. This reinforces those colonising epistemologies that converge in academic spaces, to write indigenous peoples out of history and reduce their ways of knowing and understanding as inferior to Western scholarship. Recognising that Western epistemologies and methodologies have been a key component of the colonising violence inflicted upon Indigenous and native peoples is an important facet of Indigenous Studies. The purpose of which, as Martin Nakata explains '....is not just to decolonise through revival of Indigenous Knowledge but also to defend them by reinstating Indigenous ontologies and epistemologies through the development of new frameworks to redress the submergence of Indigenous people's knowledge as it occurred through colonial regimes'. ${ }^{64}$

Considering these tensions and critiques, Rana Barakat makes an excellent case for refining the use of settler colonialism as a 'method of analysis within the larger project of indigenous studies', rather than carving it out as its own field ${ }^{65}$. Barakat, reiterating Byrd's argument, emphasizes that the focus on settler triumph and native defeat in settler colonial scholarship is problematic and results in replicating a narrative that marginalizes Indigenous people; whereas Indigenous Studies attempts to keep the focus on Indigenous understandings of invasion, rupture and transformation. Barakat's point, 
mentioned earlier, that Palestinian early work on settler colonialism is barely referenced, is a product of this problematic approach to settler colonial relations; one that seems to have led to the increasing marginalisation of knowledge developed by indigenous communities in Palestine, and the particular language they use to describe the structure of invasion (in large part because it does not accord with the lexicon that has accompanied the institutional paradigm articulated by Wolfe and Veracini). Alternatively, an Indigenous Studies framework highlights the fact that Palestinians call the cyclical and continuous process of Zionist invasion and erasure al Nakba al mustimirrah (the continuous Nakba); and emphasises that this understanding of the settler colonial condition underpins the writings and discourse of Palestinian scholars, activists and ordinary people.

Tracing this framing - and the ways it has been appropriated - starts with the term Nakba itself, which means catastrophe or disaster in Arabic; it became synonymous with what happened in Palestine in 1948 after Syrian scholar Constantine Zurayq's essay 'The Meaning of Disaster' was published in 1956. Not long after, in 1959, Walid Khalidi published a paper on the forced exodus of Palestinians that shaped the discourse and agenda for an entire generation of Palestinian scholars investigating their own history. In the following two decades, in addition to Khalidi's continued work on these themes, numerous publications shared in the work of articulating the Nakba. Among them is Nafez Nazzal, who produced one of the earliest and most extensive oral history works on Palestine, and more specifically the Western Galilee, 'Palestinian Exodus from Galilee, 1948'. ${ }^{66}$ In the 1990s, a group of Israeli-Jewish scholars, who later became known as the 'New Historians', used previously classified Israeli military and national archives to tell the same story; writing and shaping the violence of the Nakba through Israeli-Jewish experiences, for Israeli-Jewish audiences, who had long been in denial about their historical renderings of 1948. But this was not the same project. Unlike these 'New Historians', who were given much of the credit for bringing the Nakba to mainstream audiences inside Israel and elsewhere, Palestinian scholars were writing and conceptualising the Nakba from the experience of their own people. ${ }^{67}$ Palestine was the starting point from which their analysis stemmed, and in this way they produced and retained their own Indigenous framework for understanding and explaining Zionist settler colonialism, thus constituting a Palestinian response to Robert Warrior's call for indigenous 'intellectual sovereignty'. ${ }^{68}$

Working with this lens, more spaces open up from which to challenge how indigenous experience and knowledge are ordered or contained within academia; and thus turn paradigms for studying settler colonial relations on their head. An example of this can be found in Shihade's engagement with the social histories of Palestinian citizens of Israel, wherein his interlocutors 'are not informants or objects of knowledge, but [...] sources of knowledge and theorizing about the past and the present' ${ }^{69}$ Another is Zu'abi's investigations into Palestinian 'knowledge-makers': the art, culture, writings and scholars that speak from Palestinian experience, to unravel both the way Israel tells its story (as a 'democratic and modern state'), and the way Palestine's and Palestinians' stories are narrated. As she exchanges the role between who is the usual researcher and who is the usual research subject, she also breaks down the binaries between indigenous and non-indigenous knowledge, that, as Snelgrove et al argue, 'at times, has the effect of treating settler colonialism as a meta-structure, thus erasing both its contingency and the dynamics that co-constitute racist, patriarchal, homo-nationalist, ablest, and capitalist settler colonialism' ${ }^{70}$ This is also reinforced in Marcelo Swirsky's argument that we have to 'take seriously phenomena of struggle, resistance and confrontation', in explaining the incompleteness of the settler colonial project. Rather than explaining indigenous resistance and ongoing presence in settler colonial states, 'in terms of the oppressor's self-error or strategic deferment ${ }^{\prime},{ }^{71}$ the continuing nature of settler colonialism is a fact because there is a continuing structure of resistance to elimination. In refining what is central and centred in the critical study of Israel/Palestine, these authors find a way to, as Barakat argues, 'read Palestinians as the makers of Palestinian history as opposed to Palestinians as a part of a Zionist narrative'. ${ }^{72}$

Ultimately, the strength of the settler colonial analytic lies in its ability to transcend the temporal and spatial boundaries imposed on Palestine by mainstream hegemonic discourse, particularly the discourse that emerged out of Oslo and is being performed in institutional settings where Israel Studies holds sway. It also explains how the Zionist regime works to maintain its domination over 
Palestinians and Palestine. However, settler colonialism is something that happened and is happening to Indigenous people, as a destructive force that created their experiences of dispossession and loss. Thus, locating critical studies of both Israel and Palestine under the Indigenous Studies umbrella - or rather, in accordance with indigenous framings of settler colonialism - seems not only epistemically logical, but also makes a clear political commitment to re-centring the narrative around Indigenous peoples. It is a strategy for a committed anti-colonial educational praxis that unsettles and pushes for decolonisation.

\section{Concluding thoughts}

In our concluding thoughts, we wish to reflect once more on the notion of knowledge production as an anticolonial praxis and how this works to shape analyses of the Israeli state and society. The fact that the liberal knowledge matrixes that hide the modalities of Israeli settler violence and the active repression of Indigenous knowledge occurs beyond the geographical boundaries of Palestine may seem obvious. But recognising that the spaces in which this occurs are also sometimes the very spaces in which many critical scholars work within, is less so. Indeed, Tuhiwai Smith writes that the 'word itself, research, is probably one of the dirtiest words in the indigenous world's vocabulary' ${ }^{73}$ Smith elaborates that the academy is based on Eurocentric assumptions and theories claiming to be universal. We know from Edward Said's Orientalism, that imperial imaginings shape much of the hegemonic discourses on the 'East'. Importantly, however, the violence and damage done by these assumptions, theories and discourses are not limited to texts and literature. They have very real and material consequences that shape the everyday reality of Indigenous and colonised peoples. The Western academy is inseparable from this and yet it is also the site from which most of us work and write. This recognition is not meant to be a demobilising one, nor is it self-flagellating, rather it is an attempt to move beyond the impasse of this dilemma. With this in mind, Nakata writes:

All knowledge that is produced about us and all knowledge that we produce ourselves is added to the Western corpus, and thereby gets reorganised and studied via the disciplines of Western knowledge. It is important to accept this reality. However it is important as well to think about the space that the academy provides for bringing in Indigenous knowledges, histories, experiences and perspectives and to make something of it for our own purposes. ${ }^{74}$

Given our discussion above of counter-hegemony - and the fact that hegemony is a field of struggle can we then consider all spaces as potential sites for contestation? What tools do we have to turn the study of Israel into a platform for transforming settler colonial relations, when we are working from within one of the key centres of colonial hegemony, the academic arena? Again, this involves challenging how we work, whose voices are centred, and the connection we make between scholarship and praxis, between understanding settler colonialism and resisting it.

Drawing upon Ramón Grosfoguel, Anaheed Al Hardan outlines several important components towards a critical epistemology that is committed to decolonisation. As a first step, Al Hardan stresses that writers and thinkers beyond the Western canon must be included in critical epistemology and, at the same time, authentic alliances must be created in order to learn from scholars and activists in the global south ${ }^{75}$. Thus the strategy of fomenting Indigenous studies as a starting point for studying the Israeli state and society (as part of critical Palestine Studies), is also a political endeavor.

Throughout this article, we have been working towards a re-reading of Israeli state and society as part of critical Palestine studies; an epistemological starting point that would make visible and disrupt the hegemony increasingly held by Israel Studies in its reproduction of Israel as a 'normal - if complex modern state', as posited in the quote that introduced this article. We have drawn on Indigenous studies and anticolonial scholarship to make the point that the only way to do this, is to ensure that when we investigate the Israeli state and society, it is with the goal of its transformation. This is informed by a political commitment, requiring not simply that Israel is understood, but that scholars 
are in solidarity with its decolonisation - a concrete and complete project that as Yves Tuck and K. Wayne Yang argue, 'implicates and unsettles everyone and everything in the process' ${ }^{76}$

With decolonisation as the goal of this work, multiple excisions and blockages to analyses of settler colonial relations in Palestine/Israel (and modes of resisting them) shift: It challenges the idea that intellectual rigour implies a 'balanced debate', in which settler colonialism is merely a paradigm, to be considered and problematised alongside others. It also rejects the idea of Palestine as an exceptional case, or Israel as an island (or a villa), in which a unique set of logics play out. It implies 'zooming out' as Shihade argues, to see Palestine/Israel as both the site of particular convergences of territorial, capitalist and nationalist logics, and as part of global and regional processes; a space of circuits and dialectic relations that feed into and out of global capitalist and colonial intersplices. ${ }^{77}$ It encourages looking beyond the boundaries of particular states, to the larger systems of power in which they are situated and to which they contribute, and thus further subverts the idea that 'Palestine' and 'Israel' are concentrated or fixed exclusively in a particular territory. It moreover highlights the multiple and mobile frontlines that have been produced to normalise the colonial relationship with Palestine, including the academic spaces discussed here; and interrogates their participation in entrenching the Israeli state's control of the narratives that perpetuate Israel's hegemony. It implicates resistance as multi-faceted and multi-layered, anchored in a spectrum of alliances and a matrix of practices that centres indigenous leadership and framing. In light of which, it reiterates the integral link between radical scholarship and radical movements, and the need for a commitment to both in our work, as researchers of the Israeli state and anticolonial praxis.

\footnotetext{
${ }^{1}$ Binyamin Netanyahu, 'United Nations General Assembly Address' (United Nations, Ney York, 29 September 2014). Video available online: https://www.youtube.com/watch?v=YyThwJYMtlM

${ }^{2}$ UCLA Younes \& Soraya Nazarian Center for Israel Studies, 'About Us', Y\&S Nazarian Center for Israel Studies, http://www.international.ucla.edu/israel/about (accessed 1 August, 2017)

3 Magid Shihade, 'The Place of Israel in Asia: settler colonialism, mobility, memory, and identity among Palestinians in Israel', Settler Colonial Studies 6, 2 (2016): 133-141.

${ }^{4}$ Raef Zreik, 'When Does a Settler Become a Native?', Constellations, 23, 3 (2016).

5 Joseph Conrad, Heart of Darkness (London: Blackwood's Magazine, 1899): 76. This is a reference to the following quote from Conrad: "Each station should be like a beacon on the road towards better things, a centre for trade of course, but also for humanizing, improving, instructing."

${ }^{6}$ For additional details on the Brand Israel Group, see: Nathaniel Popper, 'Israel Aims to Improve its Public Image', Forward, 14 October, 2005, http://forward.com/news/2070/israel-aims-to-improve-its-public-image. Amanda Borschel-Dan, "Devastating" Survey Shows Huge Loss of Israel Support among Jewish College Students, Times of Israel, 21 June, 2017, https://www.timesofisrael.com/devastating-survey-shows-huge-lossof-israel-support-among-jewish-college-students/

${ }^{7}$ Xio Xian, "The "Belt and Road Initiative" and China-Israel Relations', Journal of Middle Eastern and Islamic Studies (in Asia), 10, 3 (2016): 1-23; Ron Cheng, 'Israel: The Next Key Player in the Cybersecurity Industry', Forbes, 27 February, 2017, https://www.forbes.com/sites/roncheng/2017/02/27/israel-the-next-key-player-inthe-cybersecurity-industry/; Haviv Retting Gur, 'Can Israel Become a Maritime Power?', The Times of Israel, 2 September, 2016, https://www.timesofisrael.com/can-israel-become-a-maritime-power/. This point about Israel's evolving relevance to international trade (due to its innovations in security, surveillance and other hightech technologies) and the infrastructure it is building to entrench these relationships, is inferred from recent journal and newspaper articles on these themes. These are a few examples.

${ }^{8}$ Marcelo Svirsky, 'Resistance is a Structure not an event', Settler Colonial Studies, 7, 1 (2017): 19-39.

${ }^{9}$ Corey Snelgrove, Rita Dhamoon and Jeff Corntassel, 'Unsettling Settler Colonialism: The Discourse and Politics of Settlers, and Solidarity with Indigenous Nations', Decolonisation: Indigeneity, Education \& Society, 3, 2 (2014): 1-32.

${ }^{10}$ Marlon Simmons and George J. Sefa Dei, 'Reframing Anti-Colonial Theory for the Diasporic Context', Postcolonial Directions in Education, 1, 1 (2012): 67-99; Andrea Smith, 'The Problem with Privilege', Andrea Smith's Blog, Posted on 14 August, 2014, https://andrea366.wordpress.com/2013/08/14/the-problem-withprivilege-by-andrea-smith/

${ }^{11}$ David Lloyd and Patrick Wolfe, 'Settler Colonial Logics and the Neoliberal Regime', 6, 2 (2016): 109-118.
} 
12 Antonio Gramsci, Selections from the Prison Notebooks of Antonio Gramsci, trans and edited by Quintin Hoare and Geoffrey Nowell Smith (London : Lawrence and Wishart, 1971); Glen Coulthard, Red Skin, White Masks: Rejecting the Colonial Politics of Recognition (Minneapolis: University of Minnesota Press).

${ }^{13}$ Coulthard, Red Skin White Masks, 152

${ }^{14}$ Ibid., 6-7

${ }^{15}$ Michel Foucault, 'The archaeology of knowledge' (Paris: Éditions Gallimard, 1969). Foucault explains how discourses emerge and transform according to relationships of power.

${ }^{16}$ Derek Penslar, 'An Inaugural Lecture: What is Israel Studies' (Inaugural Lecture, Professor of Israel Studies, St. Anne's College, University of Oxford, 2013); Hillary Aked, 'Israeli State Power and the Zionist Movement in the UK: the Case of the Counter-Campaign against the Boycott, Divestment and Sanctions (BDS) Movement for Palestinian Rights' (Doctoral Thesis, University of Bath, forthcoming 2017); Miriam Shenkar, 'The Politics of Normalisation: Israel Studies in the Academy' (Masters Dissertation, Department of Education, University of Ohio, 2010). Martin Kramer, 'The Pathology of Middle Eastern Studies' (Keynote address to the Ninth Annual Conference of the Association for the Study of the Middle East and Africa, 28 October, 2016). The initial organisation of Israel Studies into a separate disciplinary field was catalysed by the funding of the Association of Israel Studies (AIS) in 1985. According to Penslar, its founding members were spurred in large part by a reaction to the insular myths of Zionist historiography. This is very different from the current boom in the field of Israel Studies, which, if we read the work of Aked, Shenkar, and Kramer (and to some degree Penslar), seems to be anchored in a reaction (by a combination of the Israeli state, pro-Israel activists/lobbyists and philanthropists), to the politicisation of 'Western' university campuses, and the mobilisation of 'the Boycott, Divestment and Sanctions' campaign among students.

${ }^{17}$ Aked, Israeli State Power. As a sample, as Aked notes in her PhD thesis, in the UK, between 2011 and 2014 , $£ 4,459,000$ was donated to support Israel Studies programmes at five major UK universities.

${ }^{18}$ Penslar, What is Israel Studies

${ }^{19}$ Penslar, What is Israel Studies; Shenkar, The Politics of Normalisation

${ }^{20}$ Shenkar, The Politics of Normalisation

${ }^{21}$ Ben White, 'The Case for Israel (Studies): It's Not Hasbara. Honest', Ben White blog, posted 21 June, 2012, https://benwhite.org.uk/2012/06/21/the-case-for-israel-studies-its-not-hasbara-honest (Accessed 15 June, 2017); Aked, Israeli State Power

${ }^{22}$ Kramer, Pathology

${ }^{23}$ Shihade, the Place of Israel; Walter Mignolo, Epistemic Disobedience, Independent Thought and De-Colonial Freedom, Theory, Culture \& Society, 26, 7-8 (2009): 1-23; Walter Mignolo, 'The North of the South and the West of the East: A Provocation to the Question', Ibraaz: Contemporary Visual Culture in North Africa and the Middle East, 108, 6 November (2014), http://www.ibraaz.org/essays/108; Achille Mbembe, Decolonising Knowledge and the Question of the Archive, (Lecture Series, University of the Witwatersrand, Johannesburg, South Africa, 2015).

${ }^{24}$ There are clearly more sinister ways of framing Palestinian communities than through the lens of Occupation (i.e. as terrorists, illegal infiltrators, violent actors, etc...); we focused on the more 'liberal' approach, which tends to be emphasised in university syllabi.

${ }^{25}$ Amal Jamal, ‘1967 Bypassing 1948: A Critique of Occupation Studies in Israeli Critical Theory’, (Lecture, Centre for Palestine Studies, SOAS, London, 1 December, 2016); see for discussion of the problematic (and political) nature of what Jamal terms "Occupation Studies" by Israeli critical scholars.

${ }^{26}$ Telesur, 'UC Berkeley Axes 'Palestine: A Settler Colonial Analysis' Course', Telesur, 13 September, 2016, https://www.telesurtv.net/english/news/UC-Berkeley-Axes-Palestine-A-Settler-Colonial-Analysis-Course20160913-0038.html; Jillian D'Amours, 'UC Berkeley Reinstates Course on Settler Colonialism in Palestine', Middle East Eye, 19 September, 2016, http://www.middleeasteye.net/news/uc-berkeley-reinstates-coursesettler-colonialism-palestine-1454193344.

${ }^{27}$ Martin Kramer, 'The Decline of Palestine Studies', blogpost on Sandbox, posted on 18 November, 2016, http://martinkramer.org/sandbox/2016/11/the-decline-of-palestine-studies/. Kramer's post directly posits BDS as the downfall of intellectual rigour in critical Palestine Studies. While we take this with a grain of salt, it is key to how Israel Studies is being sold and legitimised within academic institutions, as a site of balanced, intellectual rigour.

${ }^{28}$ Himmat Zu'bi, 'Returning the Gaze: Indigenous Voices Examine Palestine and its Settler Society', (conference proceedings, closed workshop on 'Decolonising Knowledge Production in Settler Colonial Contexts, Middle East Centre - London School of Economics, 2017).

${ }^{29}$ Yara Hawari and Hana Sleiman, 'Challenging Knowledge Production in the British Academy: Who Can

Speak on Palestine?’, Jadaliyya, Online publication, 29 May, 2017, http://www.jadaliyya.com/pages/index/26597/challenging-knowledge-production-in-the-british-ac.

${ }^{30}$ Aked, Israeli State Power 
${ }^{31}$ Antonio Gramsci, Selections from the Prison Notebooks of Antonio Gramsci, translated and edited by Quintin Hoare and Geoffrey Nowell Smith (London: Lawrence and Wishart, 1971): 206-276.

${ }^{32}$ Paulo Freire, Pedagogy of the Oppressed, trans [from Spanish] by Myra Bergman Ramos (New York,

London: Continuum): 48

${ }^{33}$ Patrick Wolfe, 'Settler Colonialism and the Elimination of the Native', Journal of Genocide Research, 8, 4 (2006): 387-409

${ }^{34}$ Gramsci, Prison Notebooks

${ }^{35}$ Rita Dhamoon, 'A Feminist Approach to Decolonizing Anti-Racism: Rethinking Transnationalism, Intersectionality, and Settler Colonialism', Feral Feminisms, 4, summer (2015): 33

${ }^{36}$ Simmons and Dei, Reframing Anti-Colonial Theory: 91

${ }^{37}$ Ibid: $75-76$.

${ }^{38}$ Zu'bi, Returning the Gaze; Mbembe, Decolonising Knowledge; Freire, Pedagogy of the Oppressed; Linda Tuhiwai Smith, Decolonising Methodologies: Research and Indigenous Peoples (London and New York: Zed Books, 1999); Timothy Mitchell, Colonising Egypt (Berkeley and Los Angeles: University of California Press, 1991).

${ }^{39}$ Shihade, the Place of Israel; Lloyd and Wolfe, Settler Colonial Logics

${ }^{40}$ Omar Jabary Salamanca, Mezna Qato, Kareem Rabie and Sobhi Samour, 'Past is Present: Settler

Colonialism in Palestine', Settler Colonial Studies, 2, 1 (2013):1-8

${ }^{41}$ These early, foundational scholars in the field of Palestine Studies include Walid Khalidi, Laila Abu Lughod,

Rashid Khalidi, Sabri Jiryis, Fares Sayegh, Nafez Nazzal, Elias Zreik, Nur Mashala, Nahla Abdo, Edward Said, Azmi Bishara and many others.

${ }^{42}$ Lorenzo Veracini, the Settler Colonial Present (Basingstoke: Palgrave Macmillan, 2015)

${ }^{43}$ Jabary-Salamanca et al, Past is Present: 5

44 Ibid: 4

${ }^{45}$ Mandy Turner and Cherine Hussein, 'Israel-Palestine after Oslo: Mapping Transformations and Alternatives in a Time of Deepening Crisis', Conflict, Security \& Development, 15, 5 (2015): 415-424.

46 Areej Sabbagh-Khoury, 'Colonisation Practices and Interactions at the Frontier: Ha-Shomer Ha-Tza'ir Kibbutzes and the Surrounding Arab Villages at the Margins of the Valley of Jezreel/Marj Ibn 'Amer, 19361956' (Doctoral Thesis, Department of Sociology and Anthropology, Tel Aviv University, 2016). Yousef Jabareen, 'Territoriality of Negation: Co-Production of "Creative Destruction" in Israel', Geoforum 66, 2015 : 11-25; Omar Jabary-Salamanca, 'When Settler Colonialism Becomes 'Development': 'Fabric of Life' Roads and the Spatialities of Development in the Palestinian West Bank', Journal of Palestine Studies, 45, 4 (2016): 64-80; Shira Robinson, Citizen Strangers: Palestinians and the Birth of Israel's Liberal Settler State (Stanford: Stanford University Press, 2013); Magid Shihade, 'Not Just a Picnic: Settler Colonialism, Mobility and Identity among Palestinians in Israel', Biography, 37, 2 (2014):451-473. This is just a sample of those authors reshaping the field of settler colonial studies, as it relates to Palestine and Israel, and vice versa

${ }^{47}$ Rana Barakat, 'Writing/righting Palestine studies: settler colonialism, indigenous sovereignty and resisting the ghost(s) of history', Settler Colonial Studies, Published Online, 15 March, 2017, http://dx.doi.org/10.1080/2201473X.2017.1300048: 1-15. Shihade, The Place of Israel; Fayez Sayegh, The Zionist Colonization of Palestine (Beirut: Palestine Liberation Organization Research Center, 1965). In support of Barakat's point, we did our own search of JSTOR's database for citations of this early scholarship and came to similar conclusions. For example, out of 1333 entries on Palestine and settler colonialism written since 1993 (the year in which the Oslo Accords were cited), 14 cite Fayez Sayegh (1965), who is, according to Magid Shihade, the first to frame Israel and Palestine through the lens of settler colonialism. By contrast, 772 cite Patrick Wolfe's work (and of these only seven mention Sayegh).

48 See for example Fayez Sayegh important paper entitled 'Zionist colonialism in

Palestine'(Beirut: PLO Research Centre,1965), in which he describes Israel as a "settler-state" and explains that its racist characteristic is not acquired but rather "inherent in the very ideology of Zionism". Additionally George Jabbour's 'Settler Colonialism in Southern Africa and the Middle East' (Khartoum: University of Khartoum, 1970), Maxime Rodinson's 'Israel: A Settler--Colonial State' (New York: Pathfinder Books,1973) and Elia Zureik's 'The Palestinians in Israel: A study of Internal Colonialism'(London: Routledge, 1979).

${ }^{49}$ Patrick Wolfe, Settler Colonialism and the Transformation of Anthropology: The Politics and Poetics of an Ethnographic Event (London: Cassell, 1999); Lorenzo Veracini, Settler Colonialism: A Theoretical Overview (Basingstoke: Palgrave Macmillan, 2010).

${ }^{50}$ Fiona Barclay, Charlotte Ann Chopin and Martin Evans, 'Introduction: Settler Colonialism and French Algeria', Settler Colonial Studies, Published Online, 12 January, 2017, http://dx.doi.org/10.1080/2201473X.2016.1273862

${ }^{51}$ We feel this point is exemplified in Yves Tuck and K. Wayne Yang's depiction of an event in which one of the authors spoke to an audience of Liberal Arts academics of their discipline's complicity in the project of 
settler colonialism, because it taught settlers how to be indigenous. The audience's reaction - which was to nod and murmur approval - implied to the authors that they either had completely misunderstood the lecture or that they had no problem with thinking about settler erasure as essential to their education, positions, and privilege. That they were in fact comfortable with it. For more on this discussion, see: Eve Tuck and K. Wayne Yang, 'Decolonisation is not a Metaphor', Decolonisation: Indigeneity, Education \& Society, 1, 1 (2012): 8.

${ }^{52}$ Jabary-Salamanca et al, Past is Present

${ }^{53}$ Bishara Doumani, 'Palestine Versus the Palestinians? The Iron Laws and Ironies of a People Denied', Journal of Palestine Studies, 36, 4 (2007): 58-59

${ }^{54}$ Nadim Rouhana, 'Homeland Nationalism and Guarding Dignity in a Settler Colonial Context: The Palestinian Citizens of Israel Reclaim Their Homeland', Borderlands, 14, 1 (2015): p. 1; Mahmoud Mamdani, 'Settler colonialism: then and now', Critical Inquiry, 41 (2015).

55 Rouhana, Homeland Nationalism: 2

${ }^{56}$ Audra Simpson. Mohawk Interruptus: Political Life Across the Borders of Settler States (Raleigh: Duke University Press, 2014); Coulthard, Red Skin White Masks; Tuhiwai Smith, Decolonising Methodologies; Brenna Bhandar and Rafeef Ziada, 'Acts and Omissions: Framing Settler Colonialism in Palestine Studies', Jadaliyya, online publication, 14 January, 2016, http://www.jadaliyya.com/pages/index/23569/acts-andomissions framing-settler-colonialism-in

${ }^{57}$ Ibid: 2

${ }^{58}$ Steven Salaita, Intern/Nationalism: Decolonising Native America and Palestine (University of Minnesota Press: Minnesota, 2016)

${ }^{59}$ It is worth mentioning here that there have been various attempts by the UN to define Indigeneity in order to provide a framework for Indigenous rights. One such attempt was by the Special Rapporteur to the UN SubCommission on Prevention of Discrimination and Protection of Minorities, Jose Martinez Cobo, who to an extent understood the problems with imposing a set definition. Yet, Cobo himself sets historical parameters on by stating that "in many instances, the confrontation between 'inhabitants' and 'invaders' took place centuries ago", thus setting the historical context to the 'New Worlds' (Martinez Cobo, Study of the Problem of

Discrimination Against Indigenous Populations: Final report submitted by the Special Rapporteur, 1982,

Section 5, p.4). The report also draws from definitions put forward by Indigenous organizations including the World Council of Indigenous people which states “... from old-age time we have inhabited the lands where we live...". Here, geographic parameters are set and the definition does not consider those Indigenous people who live in exile. It is thus pertinent to adopt fluid and flexible understandings of indigeneity, which consider the variety of characteristics of settler colonial invasion and the variety of experiences of Indigenous peoples. ${ }^{60}$ Alissa Macoun and Elizabeth Strakosch, 'The Ethical Demands of Settler Colonial Theory', Settler Colonial Studies, 3, 2-4 (2013): 426

${ }^{61}$ This is exemplified in the increasing number of events, research projects and $\mathrm{PhD}$ dissertations utilising settler colonial analytics in examining power dynamics in Palestine/Israel that are also supported or hosted by Israeli-based institutions; as Barakat argues, positions and positionality should be and are key to how settler colonialism is framed, and thus challenged, within academic institutions. Barakat, Writing/Righting Palestine. ${ }^{62}$ Jodi Byrd, 'Follow the Typical Signs: Settler Sovereignty and its Discontents', Settler Colonial Studies, 4, 2 (2014): 151

${ }^{63}$ J. Kēhaulani Kauanui, 'Settler Colonialism Then and Now: A Conversation between Kauanui and Patrick Wolfe', Politica \& Società, 1, 2 (2012): 236

${ }^{64}$ Martin Nakata, 'Australian Indigenous Studies: A Question of Discipline', TAJA - the Australian Journal of Anthropology, 17 (2006): 268

${ }^{65}$ Barakat, Writing/Righting Palestine. Yet, even as we consider this a salient point, it is important to note (and reflect on) the fact that thus far, Settler Colonial Studies does not have its own disciplinary centres, whereas there are dozens of Indigenous Studies Centres in Western Academe. Then again, if we shift our spotlight back to Israel/Palestine, while there are dozens of posts and centres devoted to Israel Studies, there are only three Palestine Studies centres (not including the new postdoctoral post at Brown University) in Western academic institutions.

${ }^{66}$ Constantine Zurayk, The Meaning of Disaster (Beirut: Khayat, 1956); Walid Khalidi, 'Why Did the Palestinians Leave', Middle East Forum, 24, July (1959): 21-24; Nafez Nazzal, Palestinian Exodus from Galilee, 1948 (Washington: Institute for Palestine Studies, 1978)

${ }^{67}$ Examples of the so-called 'New Historians' include Ilan Pappé, Benny Morris, Avi Shlaim, Simha Flappan, Tom Segev, among others. For a comprehensive critique of their approach and re-writing of Palestinian history, see Nur Masalha, 'New History, Post-Zionism and Neo-Colonialism: A Critique of the Israeli "New Historians", Holy Land Studies, 10, 1 (May 2011): 1-53.

68 Warrior, Robert Allen (1992), 'Intellectual Sovereignty and the Struggle for an American Indian Future', WICAZO SA Review, Vol 8. (1) p1-20 
${ }^{69}$ Shihade, Not A Picnic: 77

${ }^{70}$ Zu'bi, Returning the Gaze; Snelgrove et al, Unsettling Settler Colonialism: 9

${ }^{71}$ Svirsky, Resistance is a Structure: 24

${ }^{72}$ Ibid: 2

${ }^{73}$ Tuhiwai Smith, Decolonising Methodologies: 1

${ }^{74}$ Nakata, Australian Indigenous Studies: 271

${ }^{75}$ Anaheed Al Hardan, 'Decolonising Research on Palestinians: Towards Critical Epistemologies and Research Practices', Qualitative Inquiry, 20,1 (2014): 69

${ }^{76}$ Tuck and Yang, Decolonisation is not a Metaphor: 7

${ }^{77}$ Shihade, The Place of Israel in Asia. Shiri Pasternak and Tia Dafnos, 'How Does a Settler State Secure the Circuitry of Capital?', Environment and Planning D: Society and Space, Published Online, 7 June, 2017, https://doi.org/10.1177/0263775817713209. 